\title{
Performance of dairy heifers raised on Xaraés palissadgrass (Brachiaria brizantha cv. Xaraés) pasture supplemented with two types of mineral mixture ${ }^{1}$
}

\author{
Carlos Augusto B. de Carvalho², Afonso A.C. Peres ${ }^{3}$, Linda Monica Premazzi ${ }^{4}$, \\ Pedro Malafaia ${ }^{2 *}$, Maria Inês A.B. Carvalho ${ }^{5}$, Domingos Sávio C. Paciullo ${ }^{6}$ \\ and Viviane A. Carli Costa ${ }^{7}$
}

\begin{abstract}
Carvalho C.A.B., Peres A.A.C., Premazzi L.M., Malafaia P., Carvalho M.I.A.B., Paciullo D.S.C. \& Costa V.A.C. 2014. Performance of dairy heifers raised on Xaraés palissadgrass (Brachiaria brizantha cv. Xaraés) pasture supplemented with two types of mineral mixture. Pesquisa Veterinária Brasileira 34(1):46-50. Departamento de Nutrição Animal e Pastagem, Instituto de Zootecnia, Universidade Federal Rural do Rio de Janeiro, Seropédica, RJ 23851-970, Brazil. E-mail: malafaia_ufrrj@yahoo.com.br

The effects of selective (e.g. mineral supplement formulated on the basis of nutritional and clinical examination of the herd) or commercial mineral supplementation of crossbred dairy heifers (Holstein-Mantiqueira), on daily weight gain (DWG), body condition score (BCS), age at first mating (AFM) and the intake of mineral mixture (IMM) managed on Xaraés palissadgrass pasture (Brachiaria brizantha cv. Xaraés) were evaluated from February 2006 to March 2008. Structural characteristics, forage allowance and nutritional value of Xaraés palissadgrass were also evaluated. The structural variables of pasture, allowances and nutritive value of forage, besides the DWG were only affected $(p<0.05)$ by season, with highest results for spring and summer. Throughout the experimental period (730 days), no sign of mineral deficiency was detected in heifers that ingested the selective supplement. The DWG and AFM were not influenced by the mineral mixture offered 0.52 and $0.33 \mathrm{~kg} /$ day during the spring/summer and in fall/winter for DWG, respectively, and 813 days of AFM). The IMM was higher for commercial mineral mixture than for selective (61.6 and $51.0 \mathrm{~g} /$ day respectively). The BCS was slightly higher for selective (3.17) than for the commercial (3.02) mineral mixture. Thus, the selective mineral supplement was a strategy to prevent mineral deficiency in this herd and resulted in similar performance at lower costs (e.g. due to less IMM) of crossbred heifers when compared with the commercial mineral supplementation.
\end{abstract}

INDEX TERMS: Palissadgrass, Brachiaria brizantha cv. Xaraés, dairy heifers, forage allowance, selective mineral supplementation, mineral mixture intake.

RESUMO.- [Desempenho de novilhas leiteiras em pastagem de capim-Xaraés (Brachiaria brizantha cv. Xaraés) suplementadas com dois tipos de misturas minerais.]

\footnotetext{
${ }^{1}$ Received on October 10, 2013.

Accepted for publication on November 27, 2013.

${ }^{2}$ Departamento de Nutrição Animal e Pastagem, Instituto de Zootecnia, Universidade Federal Rural do Rio de Janeiro (UFRRJ), Seropédica, RJ 23851-970, Brazil. E-mails: carloscarvalho_ufrrj@yahoo.com.br, *Coresponding author: malafaia_ufrrj@yahoo.com.br

${ }^{3}$ Departamento de Engenharia de Agronegócios, Universidade Federal Fluminense, Av. dos Trabalhadores 420, Vila Santa Cecília, Volta Redonda, RJ 27255-125., Brazil. E-mail: lelo@metal.eeimvr.uff.br
}

Foram avaliados os efeitos da suplementação mineral seletiva (i.e. aquela feita com base no exame clínico-nutricional do rebanho) ou comercial sobre o desempenho de novilhas

\footnotetext{
${ }^{4}$ Instituto de Zootecnia, APTA, SAA-SP, Rua Heitor Penteado 56, Centro, Nova Odessa, SP 13460-000, Brazil. E-mail: linda@iz.sp.gov.br

5 Pólo Regional do Vale do Paraíba, APTA, SAA-SP, Av. Prof. Manoel César Ribeiro 320, Santa Cecília, Pindamonhangaba, SP 12400-970, Brazil. E-mail: irpe2318@yahoo.com.br

${ }^{6}$ Embrapa Gado Leite, Rua Eugênio do Nascimento 610, Bairro Dom Bosco, Juiz de Fora, MG 36038-330, Brazil. E-mail: domingos@cnpgl.embrapa.br

${ }^{7}$ Animal Scientist, Rua Mário Agostinelli 50, Bloco 2, apto 502, Barra da Tijuca, Rio de Janeiro, RJ 22775-046, Brazil. E-mail: vivianecarli@ig.com.br
} 
leiteiras Holandês-Mantiqueira, com base em seus ganhos de peso diários (GMD), escores da condição corporal (ECC), idades à primeira cobertura (IPC) e consumos de mistura mineral (CMM), criadas em pastagem de capim-Xaraés (Brachiaria brizantha cv. Xaraés), no período de fevereiro de 2006 a março de 2008. Foram também avaliadas as características estruturais do pasto, oferta e valor nutritivo da forragem. Durante todo período experimental (730 dias), nenhum sinal de deficiência mineral foi detectado nas novilhas que ingeriram o suplemento seletivo. As variáveis estruturais do pasto, as ofertas e o valor nutritivo da forragem, além do GMD, somente foram influenciadas $(\mathrm{p}<0,05)$ pela estação do ano, com maiores e melhores resultados obtidos para a primavera e verão. O GMD e a IPC não foram influenciados pela mistura mineral ofertada $(0,52$ e $0,33 \mathrm{~kg} /$ dia durante a primavera/verão e outono/ inverno para GMD, respectivamente, e 813 dias de IPC). 0 CMM foi maior para mistura mineral comercial que para seletiva (61,6 e 51,0g/UA/dia, respectivamente). O ECC foi superior para mistura mineral seletiva $(3,17)$ que para comercial $(3,02)$. Esta suplementação mineral seletiva foi uma estratégia que permitiu evitar o aparecimento de estados carenciais no rebanho e obter desempenho similar e com menor custo quando comparada com a suplementação mineral comercial.

TERMOS PARA INDEXAÇÃO: Capim-Xaraés, Brachiaria brizantha cv. Xaraés, suplementação mineral seletiva, consumo de sal mineral, escore de condição corporal, ganho de peso, oferta de forragem.

\section{INTRODUCTION}

In Brazil, mineral supplementation is one of the most important components that constitute the costs of production during growing phases of dairy cattle. It is made in most cases, indiscriminately, via supplementation with commercial products containing many macro and micro minerals, often not necessary in cattle diet. The general assumption that the best mineral mixture must contain a larger number of elements included in its composition is not sustained by scientific evidence (Tokarnia et al. 2000, Malafaia et al. 2004, Peixoto et al. 2005, Tokarnia et al. 2010). These misconceptions can affect the health and animal productivity, since many elements supplemented by mineral mixtures in a non-deficient cattle diet may antagonize the absorption of others really needed (Underwood \& Suttle 1997). Therefore, some concepts and practices routinely applied in the commercial mineral supplementation in Brazil need to be reviewed.

On the other hand, selective mineral supplements are formulated on the basis of nutritional and clinical examination of a specific herd and may represent a more costeffective alternative. The use of selective mineral supplements to prevent mineral deficiency diseases could lead to performance equivalent to or better than the one when commercial mineral mixtures are used (Malafaia et al. 2004, Domingues et al. 2008).

The cultivar Xaraés is Brachiaria brizantha, collected in Burundi, Africa, was released by Embrapa in 2003, after 15 years of evaluation. It is a $1.5 \mathrm{~m}$ height grass with high leaves production, fast regrowth and late flowering, which extends the grazing period into the dry season (Embrapa 2004). These qualities make this grass highly suitable for use in livestock production. Although many studies in mineral supplementation in cattle raised in tropical pastures have been published, none of them included the evaluation and control of other variables of pastures such as forage mass allowance, morphological composition, nutritive value, forage intake and reproductive performance (especially for dairy cattle), which are essential for a meaningful evaluation.

This study aimed to evaluate cost of mineral supplementation and performance of crossbreed dairy heifers supplemented with a commercial or a selective mineral mixture during two years, raised on Xaraés palissadgrass pasture managed under controlled conditions of forage allowance and quality.

\section{MATERIALS AND METHODS}

The experiment was conducted on 7 ha of Xaraés palissadgrass (Brachiaria brizantha cv. Xaraés) submitted to a rotational management system in Pindamonhangaba/SP, during the period from $2^{\text {nd }}$ February 2006 to $3^{\text {rd }}$ February 2008 (22 grazing cycles or 730 days). The geographical coordinates of the area are $22^{\circ}$ $56^{\prime} 49 \mathrm{~S}$ and $45^{\circ} 26^{\prime} 38^{\prime \prime} \mathrm{W}$, with an average altitude of $575 \mathrm{~m}$. According to "Köppen System", the climate is classified as mesothermal type (CWA), with hot and rainy summers and dry winters. According to the Centre for Integrated Agrometeorological Information (Ciagro), the average temperature of the coldest month is around $18^{\circ} \mathrm{C}$ and the warmest month is above $22^{\circ} \mathrm{C}$. Total annual rainfall distribution varies between 1100 to $1700 \mathrm{~mm}$.

The experimental treatments consisted of two mineral mixtures. A commercial mineral mixture was used routinely for dairy cattle by farmers of the Vale do Paraíba/SP, which contained $75 \mathrm{~g} \mathrm{Na}, 200 \mathrm{~g} \mathrm{Ca}, 60 \mathrm{~g} \mathrm{P}, 20 \mathrm{~g} \mathrm{~S}, 20 \mathrm{~g} \mathrm{Mg}$, 35g K, 700mg Cu, 15mg Co, $700 \mathrm{mg} \mathrm{Fe}, 40 \mathrm{mg}$ I, $1600 \mathrm{mg} \mathrm{Mn}, 2500 \mathrm{mg} \mathrm{Zn}$ and $19 \mathrm{mg}$ Se per kg. A selective mineral mixture was made in the experimental station, based on clinical and nutritional examination of the herd and by reports of clinical or subclinical $\mathrm{P}, \mathrm{Cu}$ and Co deficiencies in the region. The selective mineral mixture contained $278.5 \mathrm{~g} \mathrm{Na}, 67 \mathrm{~g}$ $\mathrm{Ca}, 55 \mathrm{~g} \mathrm{P}, 1243 \mathrm{mg} \mathrm{Cu}$, and $63 \mathrm{mg}$ Co per $\mathrm{kg}$.

The Xaraés pasture was established in March 2005, in a flat terrain of a soil classified as Hapludult (Soil Survey Staff 1999). The fertilizer recommendations in the establishment was made following Van Raij et al. (1996) and liming and phosphate fertilization was performed for achieve satisfactory levels of $\mathrm{Ca}, \mathrm{Mg}$ and $\mathrm{P}$, which were checked by soil analyses before and during the experimental period. Fertilization for maintenance was performed with 150 and $100 \mathrm{~kg}$.ha- ${ }^{-1}$ of $\mathrm{N}$ and $\mathrm{K}_{2} \mathrm{O}$, respectively, divided into three equal doses during the rainy season (October to April).

The total area of pasture was divided into two rotational stocking systems used for the two mineral mixtures. Each system contained seven paddocks, being grazed at 30 days of interval of defoliation and five days of occupation under variable stocking rate to maintain forage allowance (FA) non less than $12 \%$ of average body weight, e.g. $12 \mathrm{~kg}$ dry mass $/ 100 \mathrm{~kg}$ of animal. In each system FA was adjusted, when necessary, through the input and output of additional animals. The weight of the experimental animals was obtained every 21 days before entering and after leaving the paddocks and was used for estimating the FA. The FA and leaf blades allowance (LBA) were estimated by calculating the ratio between the FA and LBA (in kg/ha of dry mass) and weights of heifers.

The forage mass (FM) of the pre-grazing condition was as- 
sessed over three paddocks (replications) per each mineral mixture and for grazing cycle by means of manual cutting at ground level. All the herbage mass contained in $0.5 \mathrm{~m}^{2}$ at five points (sampling units) of each paddock area $\left(4500 \mathrm{~m}^{2}\right)$ was sampled one day before the entry of animals in their next paddocks to be grazed. The forage collected after cutting for each sample was divided into weeds and dead material, pseudo stem and green leaf blades. All fractions obtained after separation were weighed on an electronic balance with a precision of $0.5 \mathrm{~g}$, sub-sampled (approximately $500 \mathrm{~g}$ ) and dried in an oven fan at $65^{\circ} \mathrm{C} / 72 \mathrm{~h}$.

The dry matter content of each morphological component (fraction) was used to estimate the dry mass of leaf blades (LBDM), stem (SDM) and dead material (DMDM), expressed as percentage (\%) of FM of the Xaraés palissadgrass. The FM provided after grazing (residues) was also estimated, fractionated and calculated in the same manner as provided in pre-grazing, but always sampled a day after the removal of the animals from grazed paddocks. The leaf blade stem ratio (LBSR) was estimated by dividing the dry mass of leaf blades by stem mass obtained in the condition of pre-grazing.

The pasture heights, in the conditions of pre (H-pre) and post grazing (H-post), were obtained from systematic sampling conducted at 40 points per paddock, on the same day of the collection of FM samples. The heights were estimated using a ruler and represented the average height of the pasture. Based on the data division of FM and LBDM, for those of $\mathrm{H}$-pre it was possible to estimate the forage bulk density (FBD) and leaf blades forage bulk density (LBFBD).

For estimation of dry matter (DM), crude protein (CP), neutral detergent fibre (NDF), and in vitro digestibility of dry matter (IVDDM) about $2 \mathrm{~kg}$ samples of green grass were collected. The samples were obtained using grazing simulation one day before the entry of the heifers in each of the three paddocks to be sampled for each grazing cycle. Subsampled (500g/subsample) were oven dried at $55^{\circ} \mathrm{C} / 72$ hours and milled to have an average particle size of $1 \mathrm{~mm}$. DM, CP and NDF were determined according to Silva (1990). IVDMD was estimated according to the protocols described by Tilley \& Terry (1963).

Twelve crossbred Holstein-Mantiqueira heifers (six per treatment) received (2-13 jan. 2007) each $10 \mathrm{~g} /$ day of $\mathrm{Cr}_{2} \mathrm{O}_{3}$ as an external marker given orally for 12 consecutive days in two daily doses of $5 \mathrm{~g}$ each at 7:00am. and 14:00 pm. After the seventh day, faeces were collected twice daily, directly from the rectum for five days. Faecal samples were dried in an oven fan at $65^{\circ} \mathrm{C} / 72$ hours and milled into $1 \mathrm{~mm}$ sieve. Chromium $(\mathrm{Cr})$ in faeces was determined by atomic absorption spectrophotometry. The faecal dry mass output was calculated by dividing the $\mathrm{Cr}$ given daily (mg/ day) by chromium existing in faecal dry matter ( $\mathrm{mg} / \mathrm{kg}$ ). Daily dry matter intake (DMI) was estimated by dividing faecal dry mass output by 1-(IVDDM/100) and expressed as percentage of the animal body weight. The heifers, in each treatment, received a concentrate, given at the $0.4 \%$ of their body weight and formulated with $12 \%$ of CP and $2.69 \mathrm{Mcal} / \mathrm{kg}$ of digestible energy throughout the experimental period. For estimation of the total daily intake of forage we discounted the amount of concentrate consumed.

For evaluation of animal performance two homogeneous groups of heifers, with an average initial weight of $140 \mathrm{~kg}$, were used for each mineral mixture containing at least ten heifers per treatment during all cycles of grazing seasons. Heifers were replaced when they became pregnant. Each group of animals had free access to mineral mixtures, water and a resting area. The average daily weight gain (DWG) and body condition score (BCS scale of 1 to 5 with increase of 0.5 units) of heifers were evaluated every 21 days during two years. The heifers were weighed always after solid and liquid fasting of 12 hours.
Daily intake of mineral mixture (IMM) was estimated weekly by the difference between the quantities offered and the leftovers of both mineral mixtures available to the animals. The amount consumed by each group of heifers was divided by the total animal units ( $1 \mathrm{AU}=450 \mathrm{~kg}$ ) of each study period (week), comprising four estimates of consumption (repetitions) per grazing cycle in all seasons.

For evaluation of age at first mating (AFM) 76 heifers were used; 38 in each treatment and the minimum of $350 \mathrm{~kg}$ of body weight was adopted for first mating. Once a heifer was mating, her age was calculated.

To evaluate the structural variables and nutritive value of pasture the randomized complete block design with two treatments (mineral mixtures) and three replicates (paddocks) for each season during four seasons (two years running) was used in a split plot arrangement. The mineral mixtures were allocated to plots and seasons in the subplots. The variables IMM, DMI, DWG, BCS and AFM were analysed by completely randomized design, in a split plot arrangement, in which the mineral mixtures were allocated to plots and seasons in the subplots. The number of animals (replications) used was at least ten for IMM, DWG and BCS, twelve for DMI and 38 for AFM.

Analyses of variance were performed with the MIXED procedure of SAS ${ }^{\circledast}$ statistical package (Statistical Analysis System), version 9.0 for Windows, which is specific for repeated measurements over time and when the time is a factor to be studied as the cause of variation. The Akaike Information Criterion (Wolfinger 1993) was utilized for choice of matrix of variance and covariance. The analysis of variance was made for mineral mixture, season and their interactions as fixed effect. Blocks or the error for the same unit over time were considered as the random effect. The "LSMEANS" was utilized to estimate the treatment means and the probability of the differences (PDIFF) was adopted to discriminate the difference between means, assuming a $5 \%$ probability of error.

\section{RESULTS AND DISCUSSION}

The structural variables and nutritive value of forage (FM, \%LBDM and DMDM, FBD, LBFBD, LBSR, \%FA and LBA, DM, $\mathrm{CP}$ and IVDMD) were only influenced $(\mathrm{p}<0.05)$ by season (Table 1 and 2). These results showed that the experimental conditions for both groups of heifers submitted to the

Table 1. Pre (H-pre) and post (H-post) heights of pastures, forage mass (FM), dry mass of leaf blades (LBDM) and of dead material (DMDM), leaf blade stem ratio (LBSR), forage bulk density (FBD) and leaf blades density (LBFBD), forage (FA) and leaf blades allowance (LBA) of Brachiaria brizantha cv. Xaraés, collected from 2 Febr. 2006 to 2 Mar. 2008

\begin{tabular}{lccccc}
\hline \multirow{2}{*}{ Variable } & \multicolumn{4}{c}{ Seasons } & SEM \\
\cline { 2 - 5 } & Spring & Summer & Autumn & Winter \\
\hline H-pre & $33.5^{\mathrm{B}}$ & $49.4^{\mathrm{A}}$ & $34.6^{\mathrm{B}}$ & $21.2^{\mathrm{C}}$ & 2.0 \\
H-post & $18.3^{\mathrm{C}}$ & $24.1^{\mathrm{A}}$ & $20.2^{\mathrm{B}}$ & $15.0^{\mathrm{D}}$ & 0.6 \\
FM (kg/ha) & $10657^{\mathrm{B}}$ & $13378^{\mathrm{A}}$ & $10943^{\mathrm{B}}$ & $9581^{\mathrm{B}}$ & 645 \\
LBDM (\%FM) & $36.4^{\mathrm{A}}$ & $34.6^{\mathrm{A}}$ & $25.0^{\mathrm{B}}$ & $26.1^{\mathrm{B}}$ & 1.8 \\
DMDM (\%FM) & $39.1^{\mathrm{B}}$ & $39.0^{\mathrm{B}}$ & $51.3^{\mathrm{A}}$ & $50.9^{\mathrm{A}}$ & 2.2 \\
LBSR & $1.54^{\mathrm{A}}$ & $1.35^{\mathrm{AB}}$ & $1.04^{\mathrm{C}}$ & $1.20^{\mathrm{BC}}$ & 0.08 \\
FBD (kg/ha/cm) & $338^{\mathrm{B}}$ & $272^{\mathrm{C}}$ & $326^{\mathrm{B}}$ & $460^{\mathrm{A}}$ & 14 \\
LBFBD (kg/ha/cm) & $120^{\mathrm{A}}$ & $91^{\mathrm{B}}$ & $80^{\mathrm{B}}$ & $116^{\mathrm{A}}$ & 6 \\
FA (\%) & $13.9^{\mathrm{B}}$ & $10.9^{\mathrm{C}}$ & $11.8^{\mathrm{BC}}$ & $19.8^{\mathrm{A}}$ & 1.3 \\
LBA (\% MS) & $7.3^{\mathrm{A}}$ & $4.9^{\mathrm{B}}$ & $3.2^{\mathrm{C}}$ & $4.0 \mathrm{~B}^{\mathrm{C}}$ & 0.6
\end{tabular}

Means with the same capital letter in the same row do not differ significantly ( $p>0.05)$. SEM is the standard error of mean. 
Table 2. Dry matter (DM), crude protein (CP), neutral detergent fiber (NDF), in vitro dry matter digestibility (IVDMD) of Brachiaria brizantha cv. Xaraés and daily weight gain (DWG) of dairy heifers, collected from 2 Febr. 2006 to 2 Mar. 2008

\begin{tabular}{lccccc}
\hline \multirow{2}{*}{ Variable } & \multicolumn{4}{c}{ Seasons } & \multirow{2}{*}{ SEM } \\
\cline { 2 - 4 } & Spring & Summer & Autumn & Winter & \\
\hline DM (\%) & $23.0^{\mathrm{A}}$ & $21.9^{\mathrm{B}}$ & $19.1^{\mathrm{C}}$ & $21.7^{\mathrm{B}}$ & 0.6 \\
CP (\%MS) & $12.9^{\mathrm{AB}}$ & $13.1^{\mathrm{A}}$ & $12.6^{\mathrm{B}}$ & $12.4^{\mathrm{B}}$ & 0.2 \\
NDF (\%MS) & $51.8^{\mathrm{B}}$ & $55.8^{\mathrm{A}}$ & $52.8^{\mathrm{B}}$ & $52.4^{\mathrm{B}}$ & 1.0 \\
IVDMD (\%MS) & $68.0^{\mathrm{A}}$ & $67.7^{\mathrm{A}}$ & $66.0^{\mathrm{B}}$ & $64.7^{\mathrm{B}}$ & 0.5 \\
DWG (kg/d) & $0.49^{\mathrm{AB}}$ & $0.56^{\mathrm{A}}$ & $0.41^{\mathrm{B}}$ & $0.25^{\mathrm{C}}$ & 0.03
\end{tabular}

Means followed by the same capital letter in the same row do not differ ( $p>0.05)$. SEM is the standard error of mean.

two mineral mixtures were well controlled and did not differ between treatments. Thus, the responses obtained for animal development and health were only derived from mineral mixtures used.

The H-pre and H-post were higher in summer, due to improved environmental conditions favourable to the development and growth of the grass prevalent in the rainy season. The morphological composition of the forage also varied with an increase in leaf blades (\%LBM) during the rainy seasons (spring and summer) and inverse behaviour of the participation of dead material (\%DMDM) in the FM during the year, with highest values in fall and winter. However there was no change ( $p>0.05)$ in the percentage of SDM component in forage mass during the seasons, which averaged $24.6 \%$. This shows that grazing management of pasture (30 days of defoliation interval and five days of grazing period) was able to provide better results, especially regarding the participation of LBDM during spring and summer (mean of $36.5 \%$ ), resulting in an average value of $4150 \mathrm{~kg} / \mathrm{ha}$ of LBDM in these seasons. In fall and winter this component accounted for only $25 \%$ of the FM, while DMDM represented approximately 40 and $50 \%$ of FM during spring and summer and fall and winter, respectively.

Another variable that confirms this tendency is the same LBSR, for which highest values were also observed in spring and summer (mean 1.44) compared to fall and winter (average of 1.06), which is consistent with the majority of results from this evaluation variable between seasons also for other grasses (Carvalho et al. 2005, Pereira et al. 2010).

The FBD and LBFBD showed the same trend, with higher values during the winter and lower values in summer, as a direct reflection of the largest pre grazing heights recorded during the summer compared to other seasons. These values were significantly higher than those typically reported in other studies (Flores et al. 2008).

The percentage of forage allowance (FA) was close to the target set $(12 \%)$ for management of pastures, except for the winter season that showed an average of $19.8 \%$. This was mainly due to a lower participation component LBDM in this season, which stipulated that lowest stocking rates were used in the winter. This can be seen when checking the lowest percentage of LBA during the fall and winter compared to those in spring and summer. It can be that the results for FA and LBA were adequate to provide good performance for heifers, based on the values obtained for DWG and considering that the Xaraés grass pasture was the main source of food and the protein-energy supplementation with $0.4 \%$ of body weight was considered at low levels for growing heifers (Pereira 2010). Evaluations of FA and LBA consist of important variables, which we analysed in this study because they were not estimated in other research carried out with selective mineral supplementation. In the present study, the lack of effect of treatments on the daily weight gain of the heifers was not affected by the amount of forage consumed by animals in both treatments.

The forage DM content was higher in spring and lower in fall, and intermediate in summer and winter (Table 2). As for the nutritional value of the forage, it appears that the values obtained for the percentage of $\mathrm{CP}$ can be considered high for tropical grasses, especially for the Brachiaria genera, for which values are usually obtained below $11 \%$, even for Xaraés grass (Flores et al. 2008). The percentage of NDF did not differ between treatments and, or, with the seasons, verifying an average value of $51.8 \%$, possibly due to the form of data collection (simulated grazing), in which almost only leaf blades and small percentage of stems were collected for analysis of nutritional value in any of the seasons.

The IVDMD coefficients can be considered high for all seasons, especially for fall and winter, possibly due to the method of collecting the samples used for forage nutritive value. Higher values were obtained for the spring and summer seasons (mean 67.8\%) and lower in autumn and winter (mean 65.3\%).

Throughout the experimental period (730 days), no sign of mineral deficiency was detected in heifers of the selective supplement group. There was a greater intake of commercial mineral mixture (IMM) in relation to the selective mixture, with a mean difference of $10.6 \mathrm{~g} / \mathrm{AU} /$ day (Table 3). These results confirm the trend of reducing costs of production systems for growing heifers, as noted by Malafaia et al. (2004) for beef cattle, because selective mineral mixtures have lower cost per $\mathrm{kg}$ and are consumed less than commercial mixtures. However, a careful review of this issue should be addressed in a specific study under a financial analysis point of view.

The DMI during the summer was not influenced $(p>0.05)$ by mineral mixture offered, with a mean value and a standard deviation of $1.9 \%(0.08)$ for body weight of

Table 3. Daily intake (IMM) of commercial and selective mineral mixture, and body condition score (BCS) of Holstein-Mantiqueira heifers managed under Xaraés grass (Brachiaria brizantha cv. Xaraés) pastures from 2 Febr. 2006 to 2 Mar. 2008

\begin{tabular}{lccc}
\hline Variable & \multicolumn{2}{c}{ Mineral mixture } & \multirow{2}{*}{ SEM } \\
\cline { 2 - 3 } & Commercial & Selective & \\
\hline IMM (g/AU/day) & $61.6^{\mathrm{A}}$ & $51.0^{\mathrm{B}}$ & 1.6 \\
BCS (1 to 5 scale) & $3.02^{\mathrm{B}}$ & $3.17^{\mathrm{A}}$ & 0.10
\end{tabular}

Means with the same capital letter in the same row do not differ significantly ( $p>0.05)$. SEM is the standard error of mean. 
heifers. This result resembles those obtained with forage plants of tropical grassland environments (Carvalho et al. 2005, Morenz et al. 2006, Flores et al. 2011), for the period of spring and summer.

The DWG of heifers did not change $(\mathrm{p}>0.05)$ with the mineral mix provided (Table 3 ), but was influenced by season, with higher values in spring and summer $(0.52 \mathrm{~kg} /$ UA) than in winter $(0.25 \mathrm{~kg} / \mathrm{UA})$. These results are a direct consequence of a better nutritive value, characterized by higher CP and IVDMD in spring and summer than in winter, and possibly lower LBA in fall and winter (Table 2). These results are similar of those found in the literature about the superiority of DWG of animals raised exclusively on pasture, with or without supplementation with concentrated feed, during the seasons of spring and summer (Flores et al. 2008, Carloto et al. 2011). For BCS there was difference between mineral mixtures, with advantage for the selective (3.17) as compared to commercial mixture (3.02), which results in improved body condition of animals in this treatment during all the seasons (Table 3). However, this observation did not reflect ( $p>0.05$ ) in the AFM of heifers, resulting in an average of 813 days of AFM for both treatments. This AFM may be considered appropriate for crossbred heifers. As BCS is made by visual evaluation and one BCS of heifer is equivalent to about $40-50 \mathrm{~kg}$, the weight difference between treatments is very small, e.g. due to 0.15 BCS unit.

\section{CONCLUSIONS}

The results of this study confirm the hypothesis of equivalent health and performance of cattle supplemented with selective mineral mixtures. However, this was the first study to prove this hypothesis by maintaining systematically, for 730 days, a pasture allowance and quality fairly closely similar for the two groups of experimental animals.

When managed under the same conditions of forage allowance and nutritive value during 2 years, the selective mineral mixture prevented mineral deficiency throughout the experimental period and resulted in similar daily weight gain and age at first mating of crossbred heifers, when compared with ones supplemented with commercial mineral mixtures.

Selective mineral supplementation was more cost-effective when compared with commercial mineral supplementation for dairy heifers.

Acknowledgments.- We acknowledge the Quarrying Society Dolomia Ltda., for facilitating this experiment in the Southern APTA experimental research station and Dr. Axel Colling (AAHL, CSIRO, Australia) and Dr. Mark Laningan (NRL, Australia) for reviewing the English version of the manuscript and valuable suggestions.

\section{REFERENCES}

Carloto M.N., Euclides V.P.B., Montagner D.B., Lempp B., Difante G.S. \& Paula C.C.L. 2011. Desempenho animal e características de pasto de capim-xaraés sob diferentes intensidades de pastejo, durante o período das águas. Pesq. Agropec. Bras. 46(1):97-104.

Carvalho C.A.B., Paciullo D.S.C., Rossiello R.O.P. \& Deresz F. 2005. Composição morfológica da pastagem de capim-elefante em relação a altura de resíduo pós-pastejo e classes de perfilhos. Bolm Ind. Anim., Nova Odessa, 62(1):45-54.

Domingues F.N., Silva J.F.C., Maldonado H., Vieira R.A.M., Ferolla F.A. \& Lista F.N. 2008. Desempenho ponderal de novilhas mestiças Holandês $\times$ Zebu submetidas a duas estratégias de suplementação mineral. Revta Bras. Zootec. 37(2):343-349.

Embrapa Gado de Corte 2004. O capim-Xaraés (Brachiaria brizantha cv. Xaraés) na diversificação das pastagens de Braquiária. Doc. 149, Embrapa Gado de Corte, Campo Grande, MS. 36p. Disponível em <http:// www.infoteca.cnptia.embrapa.br/bitstream /doc/904421/1/> Access on Dec. 21, 2012.

Flores R.S., Euclides V.P.B., Abrão M.P.C., Galbeiro S., Difante G.S. \& Barbosa R.A. 2008. Desempenho animal, produção de forragem e características estruturais dos capins marandu e xaraés submetidos a intensidades de pastejo. Revta Bras. Zootec. 37(4):1355-1365.

Malafaia P., Peixoto P.V., Gonçalves J.C.S., Moreira A.L., Costa D.P.B. \& Correa W.S. 2004. Ganho de peso e custos em bovinos de corte submetidos a dois tipos de suplementos minerais. Pesq. Vet. Bras. 24(3):160-164.

Morenz M.J.F., Silva J.F.C. \& Aroeira L.J.M. 2006. Óxido de cromo e alcanos na estimativa do consumo de forragem de vacas em lactação em condições de pastejo. Revta Bras. Zootec. 35(4):1535-1542.

Peixoto P.V., Malafaia P., Barbosa J.D. \& Tokarnia C.H. 2005. Princípios de suplementação mineral em ruminantes. Pesq. Vet. Bras. 25(3):195-200.

Peixoto P.V., Malafaia P., Miranda L.V., Canella C.F.C., Canella Filho C.F.C. \& Vilas Boas F.V. 2003. Eficiência reprodutiva de matrizes bovinas de corte submetidas a três diferentes tipos de suplementação mineral. Pesq. Vet. Bras. 23(3):125-130.

Pereira L.E.T., Paiva A.J., Silva S.C., Caminha F.O., Guarda V.D. \& Pereira P.M. 2010. Sward structure of marandu palisadegrass subjected to continuous stocking and nitrogen-induced rhythms of growth. Scientia Agricola 67(5):531-539.

SAS Institute 1996. User Software: changes and enhancements through release. Version 6.11. SAS Institute, Cary.

Silva D.J. 1990. Análise de Alimentos: métodos químicos e biológicos. Universidade Federal de Viçosa, Viçosa, MG. 166p.

Soil Survey Staff. 1999. Soil taxonomy. $2^{\text {nd }}$ ed. USDA-NRCS. U.S. Govt. Print. Office, Washington, DC. Available on-line.

Tilley J.M.A. \& Terry R.A. 1963. A two-stage technique for the in vitro digestion of forage digestibility. J. Brit. Grassl. Soc. 18(1):104-111.

Tokarnia C.H., Döbereiner J. \& Moraes S.S. 2000. Situação atual e perspectivas da investigação sobre nutrição mineral em bovinos no Brasil. Pesq. Vet. Bras. 20(3):127-138.

Tokarnia C.H., Peixoto P.V., Barbosa J.D., Brito M.F. \& Döbereiner J. 2000. Deficiências Minerais em Animais de Produção. Editora Helianthus, Rio de Janeiro. 191p.

Underwood E.J. \& Suttle N.F. 1997. The Mineral Nutrition of Livestock. CABI Publishing, London. 609p.

Van Raij B., Cantarella H., Quaggio J.A. \& Furlani A.M.C. 1996. Recomendações de adubação e calagem para o Estado de São Paulo. $2^{\text {a }}$ ed. Bolm Téc. 100, Instituto Agronômico, Campinas. 285p. 